\title{
ESTADO E ESPAÇO URBANO: REVISITANDO CRITICAMENTE AS EXPLICAÇÕES SOBRE AS POLÍTICAS URBANAS ${ }^{1}$
}

\author{
Eduardo Cesar Marques \\ Universidade de São Paulo
}

\author{
Renata Mirandola Bichir \\ Universidade de São Paulo
}

\begin{abstract}
RESUMO
Este artigo analisa as politicas de infra-estrutura urbana em São Paulo entre 1978 e 1998. Partindo de dados primários, o estudo reconstrói os investimentos públicos e a sua distribuição espacial na cidade, usando uma base construída a partir de indicadores sociais. Esse procedimento permite discutir os aspectos distributivos da política e o seu impacto sobre os habitantes do Município de São Paulo. Os resultados problematizam hipóteses presentes nas literaturas de Sociologia e estudos urbanos.
\end{abstract}

PALAVRAS-CHAVE: políticas urbanas; produção do espaço urbano; Sociologia Urbana; infra-estrutura urbana; São Paulo.

\section{INTRODUÇÃO}

Este trabalho analisa os padrões estatais de intervenção em infra-estrutura urbana no município de São Paulo, entre 1978 e 1998. São analisados os aspectos temporais, sócio-espaciais e distributivos dos investimentos da Secretaria de Vias Públicas da Prefeitura de São Paulo. As informações aqui apresentadas são originárias de uma pesquisa em andamento no CEBRAP, financiada pela FAPESP, que analisa diversos aspectos da política daquela Secretaria partindo de um amplo levantamento de informações primárias relativas a contratações entre a Secretaria e empresas privadas, publicadas no Diário Oficial do Município de São Paulo, sendo pesquisados todos os extratos de contratos da Secretaria, dia a dia, entre 1978 e 1998. O material coletado permitiu analisar as dimensões temporal, espacial e de poder presentes na política de infra-estrutura na cidade de São Paulo. Essas informações foram complementadas por uma série de entrevistas com técnicos do setor.

\footnotetext{
1 Artigo originalmente apresentado na sessão "Investimento público e produção do espaço" durante o Simpósio Cidade e poder, realizado entre 23 e 24 de abril de 2001 na Universidade Federal do Paraná, promovido pela Revista de Sociologia e Política e pelo Grupo de Estudos Cidade, Poder e Sociedade, sob coordenação do Prof. Dr. Nelson Rosário de Souza.
}

A investigação representa, em vários aspectos, uma continuação de pesquisa similar sobre políticas de infra-estrutura de saneamento no Rio de Janeiro, consubstanciada em Marques (2000). Considerando que se tratam de duas políticas altamente espacializadas, executadas diretamente por empreiteiras inseridas em comunidades de engenheiros das duas mais importantes cidades brasileiras, são inúmeros os possíveis pontos de comparação, que serão estabelecidos sempre que relevantes.

O presente trabalho discute uma série de resultados parciais da pesquisa, o que nos permite problematizar afirmações das literaturas de Sociologia e estudos urbanos. Este exercício é fundamental para que possamos iniciar a construção de um novo quadro conceitual coerente analiticamente para o estudo do urbano brasileiro, que incorpore os constrangimentos estruturais, a herança histórica das relações e instituições brasileiras, mas que deixe espaço para a análise dos atores e agentes sociais.

Após uma rápida discussão da literatura, realizada na primeira e na segunda seções, iniciamos a apresentação dos resultados pela descrição da alocação dos investimentos ao longo do tempo. A dinâmica mais geral da política no tempo, assim como a caracterização das administrações municipais, já foram abordadas por nós em outro trabalho (MARQUES \& BICHIR, 
2001), e serão apenas rapidamente descritas na terceira seção do artigo. Em seguida, a quarta seção apresentará a distribuição dos investimentos no espaço urbano paulistano, usando para tal uma base espacial construída pela agregação dos distritos censitários segundo suas características sócio-econômicas em 1997. A dinâmica dos investimentos em cada um desses espaços ao longo do tempo e por administração municipal permite problematizar hipóteses presentes na literatura, assim como impressões do senso comum sobre a política. Ao final do artigo, sumariamos os principais resultados e apresentamos nossas conclusões.

\section{PERIFERIAS, ESTADO E PRODUÇÃO DO ESPAÇO}

As literaturas sociológica e urbana dos anos 1970 e 1980 caracterizaram as periferias metropolitanas brasileiras pela completa ausência do Estado, exceto pelos empreendimentos habitacionais massificados implantados a partir do final dos anos 1960. Nossos espaços metropolitanos se caracterizariam por um gradiente decrescente de condições de vida, inserção no mercado de trabalho e acesso à renda do centro para as periferias. Os espaços periféricos seriam os mais distantes e de menor renda diferencial, ocupados pela população de mais baixa renda e inserida de menaira mais precária no mercado de trabalho (KOWARICK, 1979; BONDUKI \& ROLNIK, 1979).

De uma forma geral, o padrão espacial das carências e da segregação social teria estabelecido um sólido e identificável "modelo metropolitano brasileiro", construído nos anos 1960 no Rio de Janeiro e exportado para o resto do Brasil em uma "moda metropolitana" (SANTOS \& BRONSTEIN, 1978). Para outros, o centro irradiador desse padrão de produção do espaço estaria nas franjas dos espaços mais dinâmicos da "metrópole do subdesenvolvimento industrializado" (KOWARICK \& CAMPANÁRIO, 1988), espaço central nos processos de reprodução da "industrialização de baixos salários" (MARICATO, 1996).

Se havia consenso com relação às péssimas condições de vida nas periferias e, em termos mais gerais, aos conteúdos concretos de cada espaço da metrópole, os processos produtores do espaço eram objeto de descrições diversificadas e nem sempre compatíveis. Para alguns autores, a ausência de intervenções públicas nos espaços periféricos seria produto de mecanismos estruturais ligados à dinâmica mais geral do sistema econômico (KOWARICK, 1979; BONDUKI \& ROLNIK, 1982), seguindo a literatura internacional de então, que derivava diretamente as principais características do espaço, assim como as condições de vida nas periferias, das dinâmicas mais gerais da acumulação (LOJKINE, 1981; CASTELLS, 1983).

Segundo esse modelo teórico, então amplamente hegemônico no campo dos estudos urbanos, o Estado seria o responsável pela reprodução geral da dinâmica capitalista, tarefa que ele cumpriria através de investimentos produtivos para auxiliar a acumulação (viabilizando tanto a reprodução do capital quanto a do trabalho) e, ao mesmo tempo, através de gastos públicos que legitimassem a sociedade capitalista, ocultando o seu caráter de classe. As políticas públicas urbanas representariam investimentos produtivos, já que auxiliariam a reprodução da força de trabalho, viabilizada através do provimento dos chamados bens (ou equipamentos) de consumo coletivo. Entretanto, essas mesmas políticas também incluiriam gastos improdutivos legitimadores da ordem social, na medida em que ultrapassassem o patamar de condições de vida necessário para a reprodução dos trabalhadores. Como os gastos com a legitimação envolveriam um volume de recursos marginal e os investimentos para a reprodução da força de trabalho tenderiam a cair muito em momentos de crise, as condições urbanas de vida para os trabalhadores quase sempre deixariam a desejar. Os conflitos causados por este baixo padrão de vida seriam insolúveis na sociedade capitalista, constituindo-se em contradições do funcionamento do próprio sistema. Ao contrário da contradição principal, entretanto, essas contradições urbanas oporiam trabalhadores e Estado, ocultando o caráter de classe do conflito mas politizando-o de maneira concomitante.

O rebatimento nacional dessa perspectiva, que encontrou em Kowarick (1979) a sua versão mais bem construída em termos teóricos, integrou uma explicação para o surgimento do regime autoritário, assim como para a manutenção de patamares de pauperização muito elevados no país, mesmo em momentos de expansão econômica acelerada, como durante o milagre econômico. No Brasil, assim como em tantos outros países de capitalismo tardio, a acumulação seria possível 
apenas através da manutenção de um vasto exército industrial de reserva, que, ao contrário de ser marginal, no sentido do debate sobre desenvolvimento e marginalidade dos anos 1960, representaria um elemento indispensável em nosso padrão de acumulação. Esse processo apresentaria contornos tão selvagens que, para usarmos a expressão de Kowarick (1979, p. 59), apenas um regime político autoritário poderia sustentá-lo. $\mathrm{O}$ sistema só poderia funcionar submetendo o conjunto da força de trabalho a padrões constantes de superexploração e espoliação urbana, sendo esta última entendida como a sistemática exclusão das camadas populares do acesso aos serviços de consumo coletivo. As periferias seriam o território da espoliação, e seriam construídas e reconstruídas pelo Estado e pela própria dinâmica da acumulação.

Em um nível menos estrutural, outras pesquisas destacaram a luta concreta entre os consumidores do ambiente construído pelo acesso a seus benefícios (HARVEY, 1982), e as ações concretas de empreendedores privados e do mercado de terras (RIBEIRO, 1997). Mesmo para essa literatura, entretanto, a luta política acabava por ser determinada pelas estruturas, já que, em momentos de acirramento da luta política, o Estado seria acionado (pelas estruturas) para garantir a manutenção do sistema, agir no interesse do "capital em geral" ou mesmo de determinadas frações hegemônicas.

As raras abordagens amplas não estruturalistas também mobilizaram mecanismos econômicos. Para Vetter (1975), por exemplo, a lógica das políticas públicas urbanas estaria ligada à associação entre poder econômico e político na sociedade, levando a uma circularidade das ações do Estado. A produção do ambiente construído, portanto, seria fortemente influenciada pela localização dos diversos grupos sociais na cidade, assim como pela sua capacidade diferencial de influenciar as ações do Estado. Outros destacaram as estratégias (econômicas) dos próprios ocupantes de loteamentos que, antecipando processos de valorização da terra, atuariam como ocupantes da fronteira urbana, expandindo a cidade continuamente (SANTOS, 1982).

De uma forma ou de outra, portanto, todas as correntes dessa literatura da Sociologia e dos estudos urbanos dos anos 1970 e início dos 1980 mobilizaram mecanismos estruturais e/ou de natureza econômica para explicar a conformação da cidade e as políticas estatais, seja ligando-as ao modo de produção, em sua versão influenciada pelo marxismo estruturalista francês, seja associando-as ao comportamento econômico de agentes sociais.

Ao longo da década de 1980, essa literatura foi sucedida por um outro conjunto de trabalhos, que se tornaram crescentemente predominantes. Esses novos estudos escolheram combater a paralisia analítica advinda dos determinismos macroestruturais, através da realização de um mergulho quase antropológico na direção do nível micro, à procura dos atores, destacando o cotidiano, a experiência e a construção de identidades como base de ações coletivas e mobilizações. Esse deslocamento, apesar de ter produzido importantes avanços e estudos de excelente qualidade, especialmente sobre movimentos sociais (como Sader, 1988), acabou conduzindo a um novo impasse analítico, pela reprodução de estudos localizados e muito pouco generalizáveis. Nas palavras de Kowarick (2000), a estrutura sem sujeitos dos estudos dos anos 1970 foi substituída, em sua versão mais extrema, pelo estudo de sujeitos liberados de qualquer constrangimento estrutural ao longo da década de 1980.

Durante todo esse longo percurso, os pontos cegos da literatura sempre foram a política, entendida como campo onde se desenrolam lutas, estratégicas e conflitos reais de resultado contingente, assim como o Estado, quase nunca tratado na sua complexidade de conjunto heterogêneo de instituições dotadas de história, estrutura, identidade e interesses próprios ${ }^{2}$. Essa lacuna tem ficado cada vez mais evidente em período mais recente, quando vários estudos têm demonstrado empiricamente processos não previstos, e em alguns casos em flagrante desacordo com a literatura destacada acima. A partir do início dos anos 1990, estudos demonstraram a presença de intervenções públicas nada

\footnotetext{
2 Para uma discussão crítica detalhada dos olhares sobre as políticas estatais das literaturas marxista, neo-institucionalista e da análise setorial, ver Marques (1997). A referência é importante pois vários dos elementos presentes (e ausentes) do debate urbano são derivados do enfoque das perspectivas sobre a natureza do Estado e suas ações.
} 
desprezíveis, não apenas nos anos 1990 (D'ALESSANDRO, 1999), mas já no final dos anos 1970 (JACOBI, 1989; WATSON, 1992; MARQUES, 2000; BUENO, 2000). Esses investimentos não foram suficientes para inverter o perfil tradicional dos investimentos públicos na direção das periferias, mas indicaram que os espaços periféricos não foram totalmente desprovidos de intervenções públicas, como se considerava anteriormente ${ }^{3}$.

A primeira reação a essas evidências foi a defesa cega de pontos do paradigma anterior ou, principalmente, a colagem conceitualmente desarticulada de novos elementos e processos, tais como burocracia, hierarquias e quadro legal, a conceitos que derivam as condições de vida de dinâmicas sistêmicas. Não queremos dizer com isso que seja possível, ou desejável, abandonar os constrangimentos sistêmicos para a explicação da realidade urbana, mas destacar, ao contrário, a necessidade de integrar de modo analiticamente coerente a estrutura com a agência, tomando como base as características constituidoras do Estado e da sociedade brasileiros. Essa tarefa obviamente é de grande envergadura, e embora já tenha sido destacada anteriormente por autores como Kowarick (2000), não foi ainda enfrentada pela literatura. Só pode ser encarada como uma agenda coletiva de pesquisa e, portanto, não é ambição do presente artigo esgotá-la. Acreditamos, entretanto, que a política e o Estado no nível urbano, compreendidos em sua complexidade, podem ser excelentes pontos de partida para tal tarefa, inclusive por terem sido escassamente explorados. É nesse sentido que a apresentação e

\footnotetext{
3 Na verdade, essa questão insere-se no debate mais amplo, e até certo ponto já superado, sobre a década perdida e seus indicadores sociais (FARIA, 1992; GUIMARÃES \& TAVARES, 1994). Em termos espaciais, entretanto, a questão ainda se apresenta pela significativa mudança no tecido periférico, que se tornou bastante heterogêneo. Aparentemente, a maior parte desses espaços vivenciou nos últimos 10 anos uma generalizada melhora dos indicadores sociais médios, com a manutenção de patamares muito ruins de condições de vida e acesso a serviços públicos em espaços muito localizados, mas bastante distribuídos no território. Embora a comparação seja difícil, as condições de vida nas periferias hoje parecem ser muito piores que as das "periferias da espoliação" dos anos 1970, talvez indicando a existência de "hiperperiferias" em nossas metrópoles (TORRES \& MARQUES, 2001).
}

a problematização dos resultados da pesquisa que dá origem a este artigo podem contribuir para a constituição de tal debate.

\section{MECANISMOS NA LITERATURA: CON- FLITOS, ELEIÇÕES E POLÍTICAS DO ESTADO}

Se concordarmos com a existência de intervenções estatais anteriores ao previsto pela literatura, a principal questão analítica a responder diz respeito aos mecanismos que levaram o Estado a alterar o seu padrão histórico de investimento ou, em um sentido mais amplo, quais os mecanismos que estimularam o Estado a executar determinadas políticas, em detrimento de outras.

As literaturas de Sociologia e estudos urbanos mobilizaram basicamente dois tipos de explicação para a alteração dos padrões de investimento público urbano nos anos 1980 . No primeiro, que podemos denominar de modelo do conflito, os movimentos sociais surgidos nos anos 1970 e 1980 teriam pressionado o Estado por investimentos e, obtendo sucesso, teriam alterado o seu modo de proceder (GOHN, 1991). Em uma versão mais sofisticada do modelo, autores como Jacobi (1989) e Sader (1988) destacaram a importância de agentes pastorais, ou mesmo técnicos estatais de esquerda, como mediadores na construção de tais mobilizações, assim como ressaltaram as mudanças no ambiente político mais amplo ocorridas no período, em parte produzidas e em parte produtoras de mobilizações e movimentos. Entretanto, mesmo nessa versão mais elaborada, o Estado é movimentado basicamente pelas mobilizações populares.

O segundo mecanismo mobilizado pela literatura se relaciona com o vínculo eleitoral (FIZSON, 1990; AMES, 1995). Segundo esse modelo, os níveis dos investimentos, e mais ainda os investimentos direcionados para os pobres, tenderiam a ser mais elevados nos momentos anteriores a eleições. Os autores que utilizam esse vínculo explicativo partem de dois pressupostos. O primeiro sustenta que o comportamento predominante dos políticos é a maximização de suas chances de reeleição, obtendo prestígio e recursos políticos, quando bem-sucedidos. O segundo passo necessário para o argumento ter sentido identifica os interesses dos políticos e as ações do Estado. Caso essa identidade não exista, não há como garantir que os primeiros se transformem nas segundas. Nesse ponto, fica 
evidente a influência dos pluralistas, para os quais o Estado não existiria como construção histórica, representando apenas um espaço vazio a ser ocupado pelos grupos de interesse vitoriosos. No caso específico do Brasil, o retorno das eleições para os executivos locais (governadores, em 1982 e Prefeitos de capitais, em 1985) teria levado a um aumento dos investimentos.

Sob o nosso ponto de vista, mesmo que possamos aceitar o primeiro pressuposto, embora com ressalvas, não podemos concordar com o segundo. Políticas são implementadas por técnicos que retiram seu poder tanto do conhecimento técnico e do funcionamento da máquina estatal quanto de vínculos que estabelecem com políticos eleitos. Os políticos necessitam desses técnicos (e de seus saberes) para realizar bons governos, independente de suas diretrizes de política, pois mesmo o mais maximizador dos políticos precisa das organizações do Estado e de seus funcionários para implementar algo. Por essa razão, o modelo do vínculo eleitoral ilumina um importante mecanismo presente no comportamento de um importante ator, mas não consegue prever as ações do Estado.

Assim, mesmo em nível teórico, a existência de vínculos mecânicos entre eleições e investimentos deve ser afastada. Isso é corroborado pelas informações empíricas descritas a seguir. Entretanto, como veremos, podemos tirar proveito analítico do cálculo político dos governantes, assim como da mudança de regime político, se o mediarmos e associarmos a outros processos. Em Marques (2000), mostramos a insuficiência desses mecanismos como elementos causais isolados das ações estatais locais. Aquele estudo demonstrou a existência de significativos investimentos em saneamento nas periferias cariocas no final dos anos 1970. Esses não podem ser creditados a conflitos, já que precederam a organização da população na região. $O$ caso carioca ganha sentido se considerarmos a dinâmica institucional da então concessionária estatal da política: a CEDAE. Essa empresa tinha sido criada em 1975 pela fusão de três empresas estatais de saneamento distintas. $\mathrm{O}$ grupo que exerceu a hegemonia na fusão (originário da empresa de águas da Guanabara - CEDAG), encarou a fusão como a incorporação de uma periferia totalmente desassistida (a Baixada Fluminense) ao território da sua antiga concessão (o Município do Rio de Janeiro). Nos primeiros anos da concessão, uma das diretrizes da política disse respeito a elevar o patamar do seu atendimento ao das periferias já integradas aos sistemas da CEDAG. Esses espaços eram servidos precariamente, com padrões tecnológico e operacional inferiores, mas mesmo assim atendidos.

$\mathrm{Na}$ construção desse padrão inferior de atendimento merecem destaque duas dinâmicas. A primeira delas, desconsiderada pela literatura crítica, diz respeito à motivação que leva os técnicos estatais a expandir serviços públicos para as periferias. Como nos lembraram recentemente os neoinstitucionalistas, a reprodução simples ou ampliada dos burocratas depende do desdobramento das políticas implementadas por seus órgãos (AMENTA \& SKOCPOL, 1986). Assim, a expansão das políticas de infra-estrutura para novas fronteiras interessa a burocracias e agências, se consideramos simplesmente suas motivações ${ }^{4}$.

Por outro lado, o conteúdo e a qualidade das políticas desenvolvidas nas periferias nos anos 1970 foram limitados pela segunda dinâmica a destacar, também escassamente considerada pela literatura. Trata-se de um elemento constitutivo da cultura técnica da comunidade profissional, que denominamos de "seletividade hierárquica das políticas" (MARQUES, 2000). Esse mecanismo não se origina das estruturas da sociedade, como a "seletividade estrutural do Estado" do marxismo estruturalista, mas do "referencial" presente no setor, no sentido de Jobert e Muller (1987). Este expressa o conjunto de idéias, crenças e visões de sociedade, explícitas ou implícitas, comungadas pela maior parte dos membros da comunidade profissional das políticas urbanas. Esse conjunto de idéias influencia fortemente os enquadramentos das políticas, fazendo que os conflitos que definem quem serão os beneficiários das políticas não se dêem apenas em torno das políticas propriamente

\footnotetext{
4 Um contra-argumento poderia ser a afirmação de que os prestadores não expandiam os serviços pelo baixo poder aquisitivo da população periférica, o que tornaria os sistemas na periferia não viáveis economicamente Essa hipótese, bastante difundida na literatura (e baseada em parte na literatura estruturalista), não encontra fundamento empírico. A partir do final dos 1980, tanto as coberturas quanto as tarifas dos serviços urbanos foram sistematicamente aumentadas, e nem por isso os serviços enfrentaram problemas insolúveis de inadimplência nas áreas metropolitanas.
} 
ditas, mas também a respeito de visões de mundo, do Estado e de suas ações.

Acreditamos que o referencial do setor e da sociedade predominante entre os engenheiros dos setores de infra-estrutura urbana considera que as prioridades estatais devem seguir a estrutura social, oferecendo os serviços primeiro (e com melhor qualidade) para os grupos sociais mais ricos e escolarizados. Essa visão é generalizada e está certamente presente há muito tempo nestes setores de política, mesmo no setor saneamento (caso estudado no Rio de Janeiro), que inclui as políticas de infra-estrutura de maior impacto social. A origem dessa visão talvez esteja, em primeiro lugar, na matriz positivista da engenharia nacional (FERREIRA, 1993), que a afastou de discussões sobre política ou a associou, no máximo, à promoção do "desenvolvimento" pensado de forma abstrata, acrítica, e certamente ideológica $^{5}$. A isso se soma o fato da engenharia considerar tradicionalmente a sua atividade como a "transformação de sonhos em realidade" quando age sobre "a matéria bruta e domina as forças da natureza"6. Trata-se de uma relação entre o gênio da técnica e a natureza indomada, sem a presença de nenhum elemento humano. Quando este é incluído, aparece da forma mais abstrata e desencarnada possível - como humanidade. A particular combinação do positivismo com a ausência do campo do social levou historicamente os engenheiros à construção de uma visão da sociedade e dos seus objetos de intervenção

5 É interessante observar que os engenheiros representaram um papel importante na montagem do Estado brasileiro, participando com destaque, inclusive, de inúmeros ministérios importantes na primeira metade do século XX (GOMES, 1994). Além disso, inúmeros políticos de expressão nacional se formaram em engenharia, embora não tenham exercido a profissão. Contudo, a visão predominante na comunidade é de que os engenheiros nunca, ou quase nunca, fizeram ou se envolveram com política.

6 A primeira referência é originária de um poema de autoria do Eng. Billings, principal executivo da Light and Power nas primeiras décadas do século, intitulado Profissão de fé do engenheiro. Os versos começam com: "Tiro partido da visão que me traz o devaneio. Aplico num passe de mágica, ciência e matemática" e termina com "Eu sou o engenheiro. Eu sirvo à humanidade, transformando sonhos em realidade" (Billings, apud TELLES, 1984). A segunda referência é oriunda de um editorial da revista $O$ engenheiro de 1955 (idem, p. 724). extremamente tecnocrática e ingênua, terreno fértil para vários tipos de conservadorismo. As clivagens existentes na sociedade, por exemplo entre ricos e pobres, são encaradas tradicionalmente como elementos naturais e completamente externos ao objeto da sua prática profissional. Nessa visão, a intervenção em quaisquer dessas ordens "naturais" obviamente não deve fazer parte das atividades dos engenheiros.

Essas características foram todas reforçadas durante o regime militar, quando as políticas estatais tinham-nas como ponto de partida. Nesse sentido, talvez o mais importante efeito das mobilizações populares e dos movimentos sociais de período recente tenha sido alterar, através de suas lutas, os patamares de direitos reconhecidos socialmente. Esse deslocamento no conjunto mínimo de serviços e bens sancionado pela sociedade como justo certamente influenciou o referencial dos engenheiros, mesmo que indiretamente. Entretanto, a seletividade hierárquica ainda está presente hoje nas políticas, tanto por motivos geracionais e pelo caráter relativamente conservador da comunidade dos engenheiros, quanto pela inércia das organizações estatais nas quais ela se inscreveu ao longo do tempo.

Com relação ao vínculo eleitoral, as políticas do Rio de Janeiro estudadas por Marques (2000) apontaram resultados similares aos apresentados neste artigo. Aquela pesquisa não encontrou uma relação estatística significativa entre anos de eleições, em vários níveis (ou anteriores a pleitos), e volumes de investimentos em saneamento. A ausência de uma relação direta entre esses processos não significa que a existência de eleições livres e regulares não esteja correlacionada com níveis mais altos de gastos sociais, ou com maior responsabilização política dos governantes pelos governados, em um sentido mais geral. Como veremos, a questão do regime político, entendido como o conjunto de regras que estruturam a luta pelo poder, é extremamente importante, principalmente pela conformação do ambiente político no qual estão inseridos os atores.

A independência entre investimentos e eleições também não impede a existência de obras

\footnotetext{
7 Cf. Marques (2000) sobre o segundo programa carioca de favelas, por exemplo.
} 
realizadas com objetivos eleitorais, especialmente em áreas de baixa renda ${ }^{7}$. A independência entre os processos indica apenas que as obras "eleitorais" não são predominantes nas ações de organizações estatais complexas, como as organizações locais de cidades grandes como o Rio de Janeiro e São Paulo.

Observemos agora de que forma os investimentos em São Paulo confirmam essas hipóteses.

\section{OS INVESTIMENTOS DA SECRETARIA DE VIA PÚBLICAS}

A Secretaria de Vias Públicas é um dos principais órgãos da Prefeitura paulistana. Sua importância se expressa, primeiramente, pela sua histórica influência na estruturação do espaço paulistano ${ }^{8}$. Além disso, sua importância se expressa pela sua centralidade nos projetos políticos de vários Prefeitos do período, tanto pela realização de obras de visibilidade, quanto pelos elevados valores contratados que, como tem sido documentado pela imprensa, estão associados a financiadores de campanha e esquemas de corrupção. No período estudado, as intervenções da SVP consumiam 13\% do orçamento municipal, chegando a totalizar $27 \%$ do gasto em 1993, o que correspondeu a cerca de R \$ 2,5 bilhões (de dezembro de 1999) 9 .

Os investimentos analisados incluem 3350 contratos, além de aditamentos, retificações e aprovações de preços. Esses contratos foram vencidos por 355 empreiteiras, somando um valor global de 8,2 bilhões de reais. Uma parte expressiva desse valor foi repassado para a Empresa Municipal de Urbanização (EMURB) ${ }^{10}$, que a partir do repasse contratou obras e serviços com empresas privadas. Infelizmente, para esse conjunto de recursos (cerca de R\$ 3,5 bilhões,

\footnotetext{
8 Vários técnicos e gestores oriundos da Secretaria tiveram grande importância na estruturação do urbanismo paulistano (LEME, 1991; 1999; SIMÕES JR., 1991; OSTROWSKI, 1989). Para uma rápida história institucional do órgão, ver Marques e Bichir (2001).

9 Essa é a data de referência da pesquisa (e deste artigo), para a qual foram transportados todos os valores, depois de convertidos e atualizados financeiramente.

10 Trata-se de uma empresa pública criada nos anos 1970 para gerenciar obras e serviços de engenharia para a Prefeitura paulistana.
}

$42 \%$ dos investimentos), não contamos, até o momento, com informações que permitam caracterizar detalhadamente as intervenções contratadas. Por essa razão o presente artigo analisa apenas os investimentos contratados diretamente pela Secretaria.

Entretanto, podemos tecer algumas considerações sobre essas inversões realizadas através da EMURB a partir de dados agregados, de modo a avaliar o efeito que as informações teriam em nossas conclusões, se já estivessem disponíveis. Quase a totalidade dos repasses para a EMURB ocorreu em quatro governos: R\$ 940 milhões na administração Reynaldo de Barros, R \$ 945 milhões no governo Jânio Quadros, R\$ 1,3 bilhão na administração Maluf e cerca de R\$ 200 milhões na administração Celso Pitta. Esses recursos foram utilizados em obras de grande vulto, contratadas com empreiteiras de grande porte, tendo sido intensamente aditadas. Como veremos a seguir, os demais contratos apontam as mesmas características como altamente representativas desses governos. Em termos espaciais, por outro lado, a maior parte desses repasses foi utilizada em obras na região habitada pelos grupos sociais de maior renda e escolaridade ${ }^{11}$. Como veremos na próxima seção, esse padrão espacial de investimento também é característico dos demais contratos dos governos citados acima. Portanto, caso as informações sobre esses contratos realizados através da EMURB estivessem disponíveis, as tendências gerais por administração observadas no restante do texto não sofreriam alteração significativa, ou, se o sofressem, as tendências observadas se tornariam ainda mais intensas.

Embora a dinâmica temporal dos investimentos seja analisada detalhadamente em Marques e Bichir (2001), é relevante resumir aqui os resultados. Naquele trabalho analisamos os condicionantes dos investimentos anuais, comparando o perfil de

\footnotetext{
11 Estão incluídas na lista dos contratos realizados com os repasses para a EMURB: 1) Túnel sob o rio Rinheiros e complementos (zona sudoeste); 2) túneis sob a av. Santo Amaro e Parque do Ibirapuera e complementos (zona sudoeste); 3) mini-anel viário e obras associadas (zona sudeste); 4) estrada Jacu-Pêssego e obras associadas (zona leste); 5) Águas Espraiadas e obras complementares (zona sudoeste); 6) Vale do Anhangabaú e obras associadas (centro).
} 
inversões com o ciclo eleitoral, os recursos anuais do orçamento e variáveis políticas. Confirmando os resultados de Marques (2000) para o Rio de Janeiro, os dados mostram uma completa independência dos investimentos com relação ao ciclo eleitoral, não havendo relação significativa estatisticamente, seja com eleições locais, nacionais ou anos pré-eleitorais.

Diferentemente, encontramos associações entre os investimentos e o nível da receita da Prefeitura, a proporção do orçamento gasto na SVP e a inclinação ideológica do prefeito ${ }^{12}$. A primeira relação é negativa, enquanto as duas seguintes são positivas $^{13}$. O sentido da primeira relação é absolutamente contra-intuitivo, embora a força da relação não seja muito grande, o que indica que devemos considerar a relação com cautela ${ }^{14}$. Os números indicam que o nível de investimentos da SVP é maior quando os recursos da Prefeitura são menores, o que desmonta qualquer explicação dos investimentos baseada na disponibilidade de recursos $^{15}$. O fenômeno ainda será explorado no restante da pesquisa, mas adiantamos aqui a interpretação com a qual estamos trabalhando. A relação é inversa porque a SVP é estratégica para a maior parte dos prefeitos do período e porque a sua burocracia conseguiu imprimir um caráter inercial a seus gastos ao longo do tempo. Assim,

12 Consideramos como de direita as administrações Olavo Setúbal, Reynaldo de Barros, Salim Curitati, Jânio Quadros, Paulo Maluf e Celso Pitta (da Arena, PDS, PTB, PPB e PTN, respectivamente) e não de direita Mário Covas e Luíza Erundina (do PMDB e do PT). As três variáveis conjuntamente explicam cerca de $62 \%$ da variância medida pelo r2. Os resultados são significativos a $99 \%$.

13 Embora haja autocorrelação entre as três variáveis independentes, as correlações sofrem um efeito muito pequeno pelo seu controle. Para informações estatísticas mais detalhadas, ver Marques e Bichir (2001).

14 Embora a correlação parcial entre os investimentos e o orçamento ainda seja de 0,55 , quando controlada pela clivagem direita/esquerda e pela proporção da SVP no orçamento, o intervalo de confiança do coeficiente desta variável em uma regressão multivariada quase toca o valor zero, variando de 0,044 a 0,005 .

15 Esse resultado também deve ser considerado com cautela pela ausência dos investimentos da EMURB. Como a confiabilidade da relação não é muito grande, o resultado pode desaparecer quando incluirmos os dados dos contratos realizados através da EMURB. os elementos limitadores dos investimentos da Secretaria são apenas as escolhas políticas dos dirigentes e as dinâmicas internas ao processo de decisão, ao contrário do restante da Prefeitura, que passa a poder gastar mais apenas quando o volume de receitas se eleva.

As relações entre o volume de investimentos e as variáveis políticas são de mais fácil interpretação, além de serem mais sólidas em termos estatísticos. Ambas as variáveis indicam ou relacionam-se com escolhas. A primeira delas é do eleitorado, que ao votar em candidatos de direita ou esquerda pode prever o conjunto de políticas que eles implementarão, uma vez no poder. Restaria saber se as preferências de política dos eleitores são compatíveis com as políticas implementadas, o que foge ao escopo deste trabalho ${ }^{16}$. De qualquer forma, está comprovada a previsibilidade para o eleitor do conteúdo das políticas a partir dos posicionamentos políticos mais amplos dos candidatos na arena eleitoral, contrariamente ao que sustentam uma parte significativa da literatura e o senso comum predominante na sociedade. A segunda relação encontrada demonstra a importância dos processos de escolha no Executivo, apenas parcialmente previsíveis a partir de posicionamentos ideológicos mais amplos: a proporção do orçamento que o Prefeito e seus secretários, consultados seus apoios no ambiente político mais amplo, repassam para a Secretaria ${ }^{17}$.

Como o perfil político-ideológico do Prefeito é um dos condicionantes dos investimentos, devemos acompanhar detalhadamente as características das administrações municipais. Os dados mostram que Prefeitos de direita - Maluf, Reynaldo, Jânio, Pitta e Setúbal - caracterizamse por grandes volumes de investimentos concentrados em contratos de grande porte, que

\footnotetext{
16 Para isso seria necessário comparar informações a respeito das preferências de política das parcelas do eleitorado que votam em candidatos de diferentes inclinações ideológicas e as políticas implementadas por estes, em uma linha mais próxima ao excelente artigo de Soares (2000) do que da adotada aqui.

17 Vale destacar que ambas as variáveis comprovam uma complexidade e uma heterogeneidade do Estado incompatíveis com a maior parte da literatura de estudos urbanos.
} 
tenderam a ser aditados de maneira intensa, com valores elevados de aditamentos individuais, na sua maioria excedendo os limites legais e acompanhados de dispensas de licitação de valores muito elevados. O capital médio das empreiteiras vencedoras nessas administrações também é sistematicamente superior. O governo Curiati apresenta características próximas a estes governos, mas com particularidades que talvez se originem do seu caráter efêmero (permaneceu apenas 12 meses no cargo). No outro extremo temos os governos Covas e Erundina, ambos com gastos anuais inferiores, volumes significativos de obras pequenas e médias pouco aditadas, que foram vencidas predominantemente por empresas de menor porte. Pode-se afirmar, portanto, que prefeitos de direita e não direita diferenciam-se bastante quanto à forma de implementação de suas políticas, apesar das diferenças entre os administradores de cada grupo (MARQUES \& BICHIR, 2001).

$\mathrm{O}$ próximo elemento analisado diz respeito à concentração das vitórias nas licitações. Os resultados permitem uma comparação direta com os obtidos por Marques (2000) para as políticas cariocas. A política da SVP caracteriza-se por um padrão muito fechado de vencedores, ainda mais restrito que o já concentrado padrão carioca. No caso de São Paulo, a concentração nas 5 e 20\% maiores vencedoras foi muito grande entre 1978 e 1993 (e sempre maior no primeiro grupo que no segundo), exceto pelos dois momentos em que a Prefeitura foi ocupada por prefeitos não de direita. A partir de 1994 (com governos de direta), a concentração dos 5\% maiores caiu, mas a fatia das 50\% menores a acompanhou, apontando para uma elevação da concentração em empresas de médias a grandes.

Esse padrão de concentração atenua-se apenas nos momentos de grande oferta de recursos, quando a diversidade das empresas vencedoras aumenta. Isso indica que apenas quando os ganhos das maiores estão garantidos, as empresas da periferia do mercado de obras públicas conseguem aumentar a sua proporção de vitórias. Esse resultado é idêntico ao encontrado em Marques (2000), e confirma a hipótese desenvolvida ali com relação à existência de uma estruturação hierárquica do mercado de obras públicas, com frações dominantes que abocanham a maior parte dos contratos (e provavelmente apresentam maior lucratividade), e frações periféricas (quase certamente subordinadas no jogo do poder entre as empresas privadas), que sobrevivem das "sobras" do mercado, quando a oferta aumenta ${ }^{18}$.

Isso explica porque a distância entre a concentração de vitórias de governos de direita e não de direita é menor do que a diferença dos demais conteúdos já citados: as administrações de maior concentração de vitórias foram as de Pitta, Curiati, Reynaldo e Jânio, e os governos de menor concentração foram os de Covas, Setúbal, Erundina e Maluf. Como são os governos de direita que mais investem, e é nos momentos de abundância de recursos que as empresas não centrais no mercado conseguem aumentar a sua fatia, governos de direita com padrão extremamente concentrado de política, como a administração Maluf (grandes investimentos em poucos contratos altamente aditados), aparecem em posição de maior dispersão de vitórias que seus pares.

Esses mecanismos são interessantes, não apenas analiticamente, mas em termos normativos, pois indicam a complexidade dos processos políticos que operam no setor e demonstram as dificuldades em se democratizar as vitórias em licitações. Não basta o interesse de desconcentrar vitórias por parte dos decisores públicos não de direita ${ }^{19}$, já que a concentração se define simultaneamente dentro do Estado e no interior do setor privado, entre os empreiteiros. Assim,

\footnotetext{
18 Vale destacar o paralelo entre esse mecanismo e a hipótese expressa anteriormente com relação aos gastos das Secretarias. Caso a hipótese esteja correta, haveria também naquele caso uma hierarquia de agências na Prefeitura: a SVP, pelo seu peso político e pela capacidade de sua burocracia gastar, teria a sua fatia mínima assegurada, sobrando para as outras Secretarias um "resto" do orçamento, passível de elevação apenas quando a receita aumentasse. Essa lógica seria revertida apenas parcialmente quando o Prefeito pertencesse a um partido não de direita, já que apenas uma parte da correlação entre investimentos e fatia do orçamento gasto na SVP é explicada pela autocorrelação dessa última variável com a inclinação político-ideológica do Prefeito.

19 Podemos aceitar a existência desse interesse pelo discurso "nativo" de técnicos de destaque de governos não de direita, mas também pela posição estratégica ocupada por tais decisores no jogo político: operando em um setor de hegemonizado pela direita (e que representa em grande parte o apoio financeiro de suas campanhas), as administrações não de direita têm todo o interesse em transformar o campo de poder do setor à medida que operam a política.
} 
alguns momentos podem ser marcados simultaneamente pela concentração de vitórias e pela implementação de mecanismos democratizadores das licitações, por exemplo reduzindo capitais mínimos e outros "dirigismos" 20 . Isso aconteceria sempre que existisse um pequeno volume de recursos disponível em contratos, assim como quando os atores hegemônicos do setor privado jogarem contra a política. Esses momentos são característicos de administrações não de direita e podem ser marcados pela ocorrência de "greves do capital" contratista, no sentido de Block (1981). Como atestam entrevistas, essa situação caracterizou o início da administração Erundina.

As informações indicam ainda que a dinâmica da concentração das licitações da SVP também sofre a influência da legislação sobre licitações, como já verificado por Marques (2000). A concentração tendeu a ficar estável entre 1978 e 1986, havendo uma tendência nítida de desconcentração a partir daquele ano, quando se promulgou a primeira legislação federal sobre licitações. A próxima mudança do perfil de concentração ocorreu a partir de 1993, quando se promulgou um novo quadro legal sobre licitações e contratos do setor público. O efeito dessa vez foi o aumento da concentração, confirmando aparentemente a hipótese dos que sustentavam, à época, que o caráter muito restritivo da nova legislação elitizaria o mercado. O impressionante paralelismo entre o Rio de Janeiro e São Paulo nos dois momentos de mudança do quadro legal não deixa dúvidas de que o fenômeno interveniente é de natureza nacional e institucional (MARQUES, 2000, p. 197; MARQUES \& BICHIR, 2001) ${ }^{21}$.

\section{INVESTIMENTOS NO ESPAÇO}

Para analisarmos os investimentos no espaço, necessitávamos de uma base espacial que ordenasse a sua distribuição. Essa etapa

20 Para uma análise política dos vícios em licitações, ver Marques (2000, cap. 5).

21 O coeficiente de correlação entre as duas curvas é de 0,54 , significativo a $5 \%$, mas deixa de ser significativo quando controlado pelo tempo. As correlações entre as curvas e o tempo (medido em anos) não são significativas entre o início do período e 1986, mas entre 1986 e o final do período são significativas a $99 \%$ e iguais a $-0,785$ (SVP) e $-0,562$ (CEDAE). metodológica é necessária pela existência na pesquisa de alguns milhares de contratos com abrangências espaciais distintas. Algumas dessas contratações incidem sobre espaços limitados e outras atingem regiões inteiras da cidade, cuja visualização simultânea é virtualmente impossível sem alguma forma de agregação e consolidação. Escolhemos construir uma base espacial especialmente para o estudo, partindo da agregação de espaços pelas características sócio-econômicas das suas populações, seguindo as recomendações de Marques (1998). Esse procedimento tem por objetivo escapar dos problemas metodológicos que adviriam da utilização de um modelo pré-concebido de distribuição dos grupos sociais no espaço, como um modelo radial-concêntrico, ao longo de eixos de transporte ou em setores circulares, induzindo o resultado final pela forma de agrupar as informações. Os espaços descritos a seguir não são homogêneos socialmente, o que seria necessário para analisar a distribuição da estrutura social no espaço. Entretanto, como a base é utilizada aqui como mero passo metodológico para o estudo dos investimentos, podemos considerar que nossos espaços delimitam áreas de características suficientemente similares.

\section{V.1. A BASE ESPACIAL}

Para a construção da base espacial, partimos de informações sócio-econômicas disponíveis pela pesquisa de origem-destino (OD) de 1997 da Companhia do Metrô. As informações foram agrupadas nos 96 distritos censitários utilizados pelo IBGE em 1991, usando para tanto ferramentas de Sistema de Informações Geográficas ${ }^{22}$.

$\mathrm{Na}$ construção da base, foram utilizadas as variáveis que se encontram descritas no Anexo Metodológico, presentes na pesquisa OD ou obtidas por manipulações algébricas a partir das variáveis da pesquisa, incluído informações referentes a estrutura etária, migração, ocupação, escolaridade, renda, estabilidade do vínculo empregatício e setor de atividade.

As informações dos distritos foram submetidas à análise fatorial por componentes principais, sendo utilizados os três primeiros fatores. Os fatores apresentam a seguinte descrição:

\footnotetext{
22 Para maiores detalhes, ver o anexo metodológico ao final do artigo.
} 
a) fator 1: Elitização (separa unidades com populações nos extremos da estrutura social): é positivamente correlacionado com alta renda e escolaridade, idade média, presença de aposentados e pensionistas, emprego estável (ocupação constante e carteira assinada), especialmente no setor de serviços creditícios e financeiros; profissionais liberais e empregadores; alta proporção de domicílios alugados, e é negativamente correlacionado com mão de obra industrial e da construção civil.

b) fator 2: Consolidação do distrito (separa unidades consolidadas de unidades de ocupação mais recente e de população jovem e em crescimento): é positivamente correlacionado com idade média, aposentados e pensionistas, mão de obra no setor de serviços, particularmente no setor de serviços creditícios e financeiros e negativamente correlacionado com imigração recente.

c) fator 3: Ocupação central (separa unidades com população precariamente inserida no mercado de trabalho, onde a ocupação segundo o modelo periférico de produção do espaço não está presente). O fator separa basicamente as unidades do centro da cidade de todas as demais, sendo positivamente correlacionado com domicílios alugados, mão de obra no comércio, trabalhadores autônomos, primeiro grau completo e negativamente correlacionado com mão de obra na construção civil e na agricultura.

Os Mapas 1, 2 e 3 a seguir apresentam a distribuição dos fatores por distrito. Como podemos ver, a distribuição dos fatores apresenta uma lógica espacial visível. O fator 1 apresenta uma estrutura radial-concêntrica, embora não perfeita. Os fatores 2 e 3 apontam para fenômenos mais diretamente urbanos, sendo que o segundo fator destaca basicamente os distritos de ocupação mais antiga e consolidada, e o terceiro separa as ocupações mais centrais do restante da cidade ${ }^{23}$.

23 Vale ressaltar que quase todas as variáveis de entrada da análise fatorial se referiam a atributos da população moradora de cada local, e não do espaço em si. O fato de o resultado apresentar um comportamento espacial regular apenas comprova a solidez da análise, assim como a relação entre os espaços da cidade e a estrutura social.
Mapa 1

Distribuição do fator de elitização por distritos

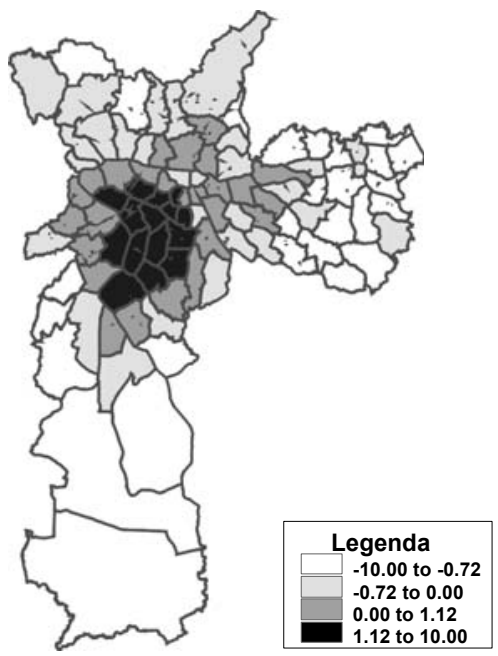

Mapa 2

Distribuição do fator de consolidação por distrito

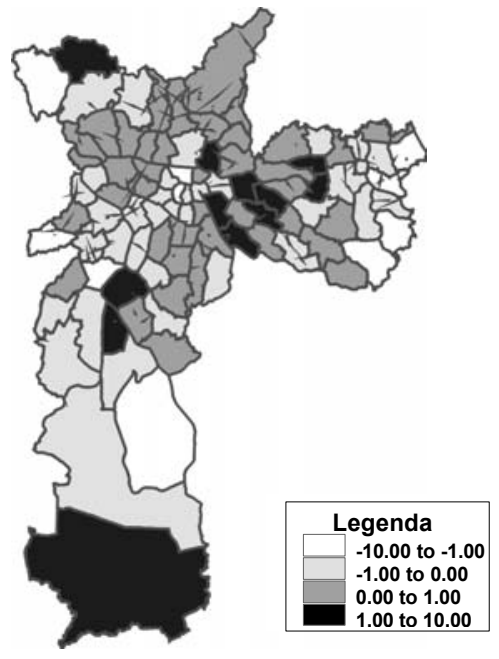

Mapa 3

Distribuição do fator de ocupação central

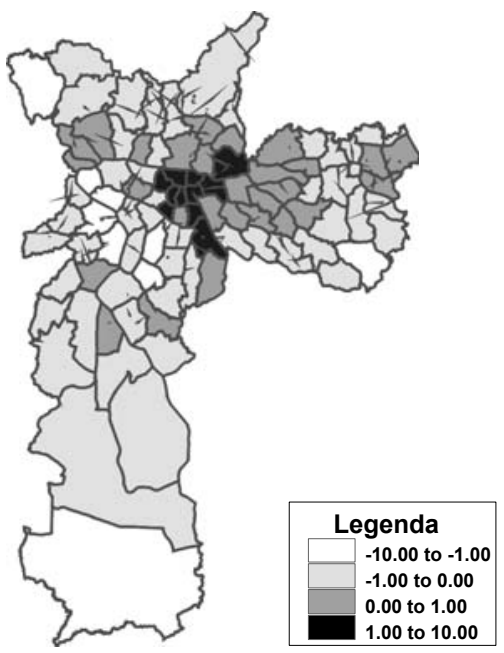


Esses três fatores foram submetidos à análise de cluster, que agregou os distritos em seis grupos, além de uma unidade isolada. Esta unidade apresentou conteúdos muito diferentes de todas as demais, especialmente pela presença expressiva de ocupados no setor agrícola - Marsilac, a unidade mais ao sul do Município. Por ser totalmente atípica e não apresentar especial interesse para os investimentos e/ou para a política, a unidade foi retirada da análise. Os seis grupos de unidades foram caracterizados pelos seus fatores médios, representando o seguinte:

a) Grupo 1 - Centro (4 distritos, cerca de $150 \mathrm{mil}$ habitantes). Esse é o único grupo construído partindo não apenas dos conteúdos sociais das suas unidades (todas com o fator de ocupação central muito alto), mas também das atividades que lá ocorrem. Três das quatro unidades (Sé, Brás e Bom Retiro) apresentam conteúdos muito similares, e a quarta unidade (República) apresenta conteúdos sociais um pouco diferentes, especialmente pela presença de maior escolaridade e renda que as demais (fator de elitização elevado). Considerando que a importância desses espaços para a cidade está muito mais relacionada com as atividades localizadas na região do que com a sua população, optamos por agregar as quatro unidades em um único grupo.

b) Grupo 2 - Ricos (13 unidades, cerca de 1 milhão de habitantes). Esse grupo é caracterizado por um alto grau de elitização, uma vez que apresenta alto valor médio no fator de elitização e muito baixo no fator de ocupação central.

c) Grupo 3 - Pobres em bairros consolidados ( 28 unidades, cerca de 3 milhões de habitantes). Esse cluster é caracterizado pela estabilidade da ocupação e pela precária inserção social da sua população, uma vez que apresenta valor elevado no fator de consolidação e baixos valores médios dos fatores de elitização e de ocupação central.

d) Grupo 4 - Classe média baixa (19 unidades, cerca de 1,5 milhão de habitantes). Valores altos no fator de consolidação do distrito e médios no fator de ocupação central.

e) Grupo 5 - Pobres em bairros recentes (18 unidades, cerca de 2 milhões de habitantes). Apresenta valores baixos em todos os fatores, em especial no de elitização.

f) Grupo 6-Classe média (13 unidades, cerca de 1 milhão de habitantes). Apresenta valor médio alto no fator de elitização e valores médios baixos nos outros dois fatores.

O Mapa 4 a seguir apresenta a distribuição dos distritos nos agrupamentos descritos acima. A sua distribuição tende ao radial-concêntrico, seguindo os fatores (Mapas 1 a 3). Os ricos se localizam a sudoeste da área central e a classe média se distribui relativamente ao seu redor. A classe média baixa tende a se posicionar imediatamente a leste da área central, embora existam distritos com conteúdos similares a norte e a sul. Em uma coroa intermediária temos os distritos que alojam prioritariamente pobres consolidados e, em uma coroa externa a esses, os pobres em áreas recentes.

Mapa 4

Distribuição dos grupos de unidades - Município de São Paulo

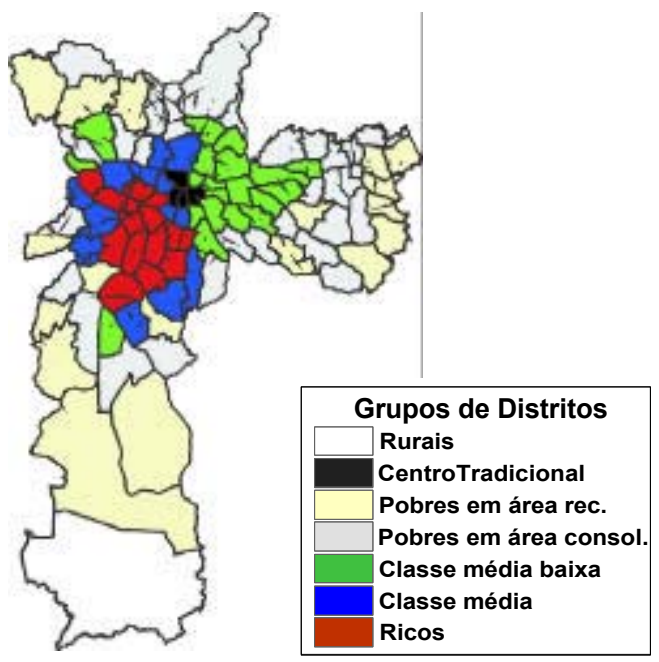

\section{V.2. DISTRIBUIÇÃO ESPACIAL DOS INVES- TIMENTOS POR ANOS (1978 A 1998)}

A Tabela 1 seguir apresenta os investimentos por grupo. A distribuição espacial da política indica que a maior proporção dos investimentos foi destinada aos espaços de pobres em bairros consolidados (R\$ 12,2 mil per capita, cerca de $27 \%$ do total), seguidos pelas áreas de classe média baixa (R\$ 10,7 mil pc, 24\%), classe média ( $\mathrm{R} \$ 9,2 \mathrm{mil}$ pc, 20\%) e áreas de população pobre em bairros recentes (R\$ 5,7 mil pc, 13\%). Os menores investimentos per capita foram destinados para as áreas centrais e das classes altas, com aproximadamente a mesma participação (R\$ 3,8 mil pc, também cerca de $8 \%$ ). Essa distribuição dos investimentos entra em desacordo com a maior parte da literatura, para a qual as periferias, até recentemente, teriam 
recebido muito menos investimentos per capita do que as áreas habitadas pela população de maior riqueza.

Os investimentos também ocorrem antes do que considera a descrição clássica da literatura sobre as periferias, como podemos ver no Gráfico
1. Os investimentos em áreas pobres recentes foram proporcionalmente os mais elevados entre 1982 e 1985, enquanto que as áreas de pobres consolidados recebem investimentos expressivos desde 1978 (R\$ 1 154,00 pc) ${ }^{24}$. Em termos percentuais, os investimentos neste último setor ultrapassam 50\% em 1989, 1990, 1993 e 1998.

Tabela 1

Investimentos per capita por grupo de distritos e tipo de espaço (em reais de dezembro de 1999, por habitante)

\begin{tabular}{|c|c|c|c|c|c|c|c|c|c|c|c|c|c|c|c|c|c|c|c|c|c|c|c|}
\hline \multirow[t]{2}{*}{ Grupo } & \multicolumn{23}{|c|}{ Anos } \\
\hline & 1978 & 1979 & 1980 & 1981 & 1982 & 1983 & 1984 & 1985 & 1986 & 1987 & 1988 & 1989 & 1990 & 1991 & 1992 & 1993 & 1994 & 1995 & 1996 & 1997 & 1998 & 1999 & Total \\
\hline $\begin{array}{c}\text { Centro } \\
\text { tradicional }\end{array}$ & 216 & 596 & 142 & 282 & 16 & 1 & 0 & 0 & 433 & 594 & 991 & - & 13 & 1 & 0 & 2 & 26 & 116 & 47 & - & 8 & - & 3484 \\
\hline $\begin{array}{l}\text { Pobres em } \\
\text { bairros } \\
\text { recentes }\end{array}$ & 371 & 80 & 698 & 506 & 768 & 346 & 132 & 347 & 234 & 609 & 550 & 1 & 51 & 1 & 1 & 7 & 17 & 160 & 564 & 6 & 8 & 260 & 5715 \\
\hline $\begin{array}{l}\text { Pobres em } \\
\text { bairros } \\
\text { consol. }\end{array}$ & 1153 & 472 & 876 & 922 & 1245 & 129 & 155 & 433 & 837 & 1350 & 1021 & 16 & 522 & 33 & 9 & 136 & 149 & 634 & 1368 & 294 & 354 & 130 & 12227 \\
\hline $\begin{array}{c}\text { Classe } \\
\text { média baixa }\end{array}$ & 734 & 527 & 1022 & 730 & 649 & 634 & 41 & 368 & 1919 & 621 & 938 & 1 & 224 & 55 & 4 & 9 & 442 & 1280 & 392 & 28 & 89 & 52 & 10759 \\
\hline $\begin{array}{l}\text { Classe } \\
\text { média }\end{array}$ & 442 & 1198 & 929 & 1532 & 810 & 79 & 14 & 103 & 437 & 227 & 156 & 3 & 29 & 51 & 8 & 23 & 32 & 455 & 1511 & 1077 & 80 & 49 & 9245 \\
\hline Classe alta & 810 & 212 & 250 & 171 & 50 & 47 & 13 & 57 & 73 & 328 & 318 & 8 & 179 & 4 & 12 & 67 & 181 & 630 & 236 & 38 & 93 & 35 & 3811 \\
\hline Total & 3726 & 3086 & 4214 & 4303 & 4678 & 1275 & 355 & 1316 & 3934 & 3729 & 3973 & 29 & 1019 & 145 & 34 & 244 & 846 & 3275 & 4118 & 1443 & 632 & 525 & 46897 \\
\hline \multirow[t]{2}{*}{$\begin{array}{c}\text { Espaços } \\
\text { polares }\end{array}$} & \multicolumn{23}{|c|}{ Anos } \\
\hline & 1978 & 1979 & 1980 & 1981 & 1982 & 1983 & 1984 & 1985 & 1986 & 1987 & 1988 & 1989 & 1990 & 1991 & 1992 & 1993 & 1994 & 1995 & 1996 & 1997 & 1998 & 1999 & Total \\
\hline $\begin{array}{c}\text { Classes } \\
\text { baixas } \\
\text { (pobre } \\
\text { recente e } \\
\text { consol.) }\end{array}$ & 1525 & 553 & 1574 & 1427 & 2012 & 475 & 287 & 779 & 1071 & 1959 & 1571 & 17 & 572 & 34 & 10 & 143 & 166 & 794 & 1932 & 300 & 362 & 390 & 17942 \\
\hline $\begin{array}{c}\text { Classes } \\
\text { altas } \\
\text { (alta e } \\
\text { média) }\end{array}$ & 1252 & 1410 & 1179 & 1704 & 859 & 126 & 27 & 160 & 510 & 555 & 473 & 11 & 209 & 55 & 20 & 90 & 212 & 1085 & 1747 & 1115 & 173 & 84 & 13056 \\
\hline
\end{tabular}

Fonte: Diários Oficiais do Município.

Gráfico 1

Distribuição dos investimentos por tipo de espaço

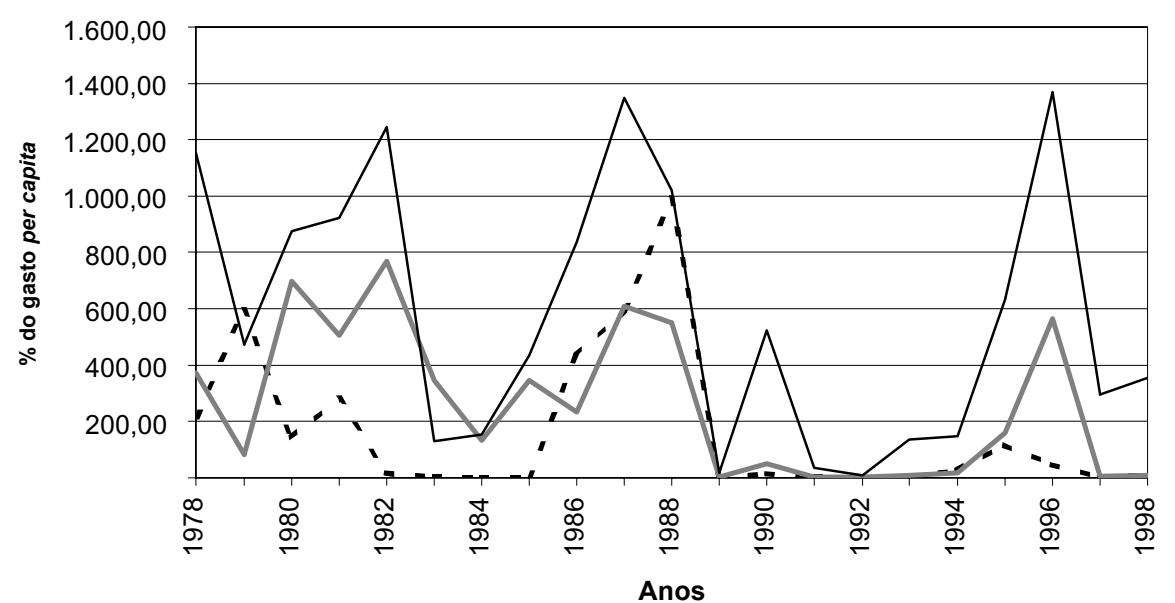

- - centro trad. $\longrightarrow$ pobr. em bairro rec. $\longrightarrow$ pobr. em bairro cons.

24 Toda a questão dos investimentos poderia ser alterada com a inclusão dos investimentos da EMURB, em especial a 
A precocidade dos investimentos nas periferias colide com uma parte significativa da literatura. Ainda no regime militar, com eleições indiretas (para governadores) ou inexistentes (para Prefeitos de capitais) para os governos locais, as periferias recebiam investimentos vultosos, relativamente. As regiões mais beneficiadas foram as sul e leste, o que seria compatível com uma explicação baseada nos movimentos sociais. Essas regiões, de acordo com Gohn (1991), Jacobi (1989) e Sader (1988), abrigaram movimentos expressivos, embora localizados, já no início da década de 1970 . Entretanto, como tomar mobilizações difusas e dispersas - de clubes de mães a movimentos de saúde, passando por ocupações de terra e reivindicações de creches - como elemento explicativo para investimentos específicos em infra-estrutura, a maior parte deles localizados em outros bairros da região? A compreensão mecânica do papel dos movimentos não dá conta desses fenômenos. Entretanto, se consideramos as mobilizações como um dos elementos da mudança de ambiente político que emoldura a passagem do regime autoritário para o democrático, podemos obter maiores progressos. Voltaremos a esse ponto mais adiante.

Por fim, vale dizer que não obtivemos resultados significativos estaticamente de possíveis influências, nos investimentos nos espaços polares e por grupo, da inclinação ideológica do Prefeito, do ciclo eleitoral, do orçamento na SVP e do orçamento municipal.

Sumariando, podemos dizer que o perfil de in- vestimentos nas periferias apresenta uma dupla tendência. A primeira envolve investimentos em áreas periféricas de ocupação mais recente, não muito elevados, mas mesmo assim expressivos. Estes ocorrem mais cedo do que se considera comumente, alguns deles ainda durante o regime militar, antes das eleições para governadores (1980, 1981 e 1982) e quando movimentos urbanos expressivos já haviam surgido e se encontravam ativos, mas ainda não haviam se estruturado em associações mais amplas ${ }^{25}$. A segunda tendência atinge espaços pobres de ocupação mais consolidada e envolve investimentos mais altos, que se iniciam mais tarde, especialmente na segunda metade da década de 1980.

As áreas habitadas predominantemente por grupos sociais mais bem inseridos socialmente também acrescentam informações interessantes, como podemos ver na Tabela 1 e no Gráfico 2 . As áreas de classe média baixa apresentam valores per capita elevados em 1980 (R\$ 1 022,00), 1986 (R\$ 1919,00$)$ e 1995 (R\$ 1 279,55). Em termos relativos, os seus anos mais expressivos foram 1983 com 49,72\% dos investimentos, 1986 com $48,78 \%$ e 1994 com 52,19 \%. Os investimentos per capita em espaços de classe média também variaram bastante. Merece destaque o ano de 1997, em que $74,66 \%$ dos gastos foram empregados nestas áreas (R\$ 1 077,00 per capita). As áreas de classe alta, apesar de não serem tão significativas ao longo de todo o período (baixos valores per capita), receberam $27,8 \%$ dos investimentos em 1989, 34,33\% em 1992 e 27,43\% em 1993.

Gráfico 2

Distribuição dos investimentos por tipo de espaço

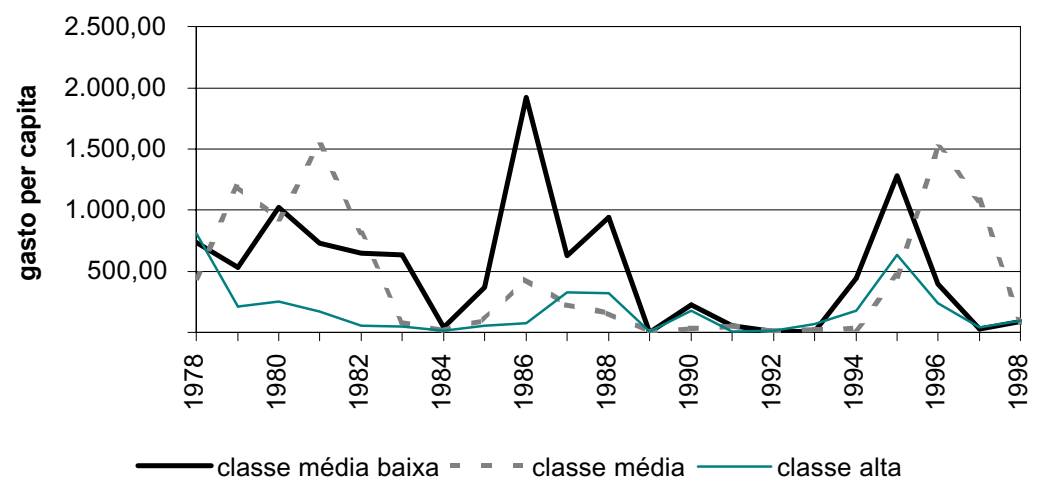

distribuição dos investimentos para todo o período e os perfis de investimentos por espaço depois de 1987, quando se iniciaram os repasses para a EMURB. Entretanto, o conjunto de investimentos em espaços periféricos no início do período não seria alterado, nem em termos absolutos nem relativos.
25 Testamos a coincidência entre a localização dos investimentos nos bairros e o início das mobilizações mais importante descritas pela literatura, mas não obtivemos resultados minimamente sólidos. 
Podemos analisar com mais clareza a tendência distributiva das políticas observando dois espaços polares socialmente. Em um primeiro podemos agregar as áreas de pobres em bairros consolidados e recentes, denominando o espaço de "classes baixas". Em um pólo oposto, denominado de "classes altas", podemos reunir os dados dos espaços das classes média e alta. Os investimentos nestes espaços polares também foram incluídos na Tabela 1, assim como no Gráfico 3.

Gráfico 3

Distribuição dos investimentos por espaço

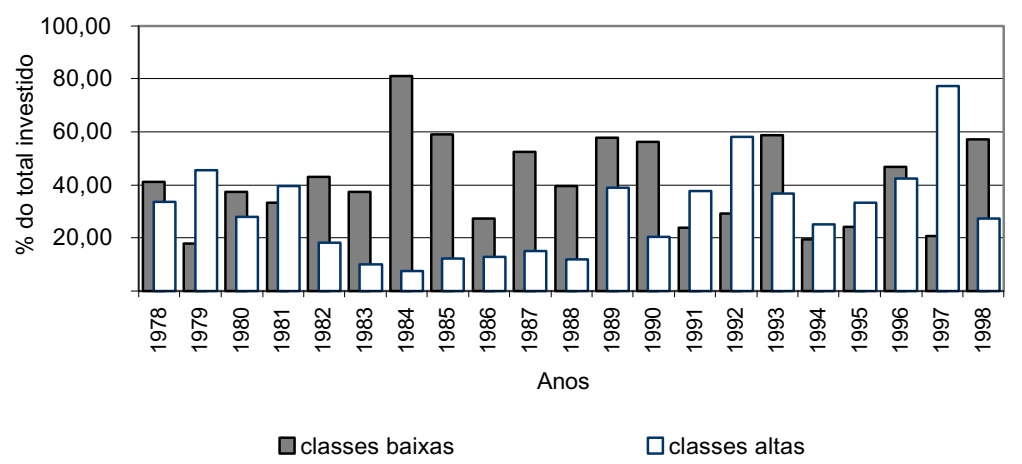

Essas informações confirmam a precocidade dos investimentos nas periferias: as inversões per capita em espaços de classes baixas superam os em áreas de classes altas em 1978, de 1980 a 1990, em 1993, 1996 e 1998, sendo que em 1984 as classes baixas receberam $80,9 \%$ dos investimentos. A partir de 1989 surge uma tendência à elevação dos gastos per capita em áreas de classes altas, com picos significativos em 1992 (58,19\%) e 1997 (77,29\%).

Em termos estatísticos, usando testes de médias, correlações parciais e regressões, não é possível sustentar a existência de qualquer relação entre os investimentos anuais por espaço de um lado e, de outro, a inclinação ideológica do prefeito, o ciclo eleitoral, a proporção do orçamento municipal gasto na SVP ou o nível global desse mesmo orçamento. Se aplicarmos os mesmos tipos de análise quantitativa às proporções dos investimentos nos dois espaços polares, também obteremos resultados não significativos estatisticamente.

\section{V.3. DISTRIBUIÇÃO ESPACIAL DOS INVES- TIMENTOS POR ADMINISTRAÇÃO}

A dinâmica temporal pode ser reorganizada por administração, de modo a caracterizar os governos em termos distributivos. Essa informação é apresentada na Tabela 2 a seguir.

Tabela 2

Investimentos por administração e grupos espaciais

\begin{tabular}{|c|c|c|c|c|c|c|c|c|c|c|c|c|c|c|c|c|c|c|}
\hline & \multicolumn{18}{|c|}{ Administrações } \\
\hline Grupos & Setúbal & $\%$ & Reynaldo & $\%$ & Curiati & $\%$ & Covas & $\%$ & Jânio & $\%$ & Erundina & $\%$ & Maluf & $\%$ & Pitta & $\%$ & Total & $\%$ \\
\hline $\begin{array}{l}\text { Pobres em } \\
\text { bairros } \\
\text { recentes }\end{array}$ & 451,5 & 6,6 & 1710,2 & 14,7 & 481,6 & 20,2 & 592,7 & 28,3 & 1392,8 & 11,9 & 53,9 & 4,4 & 748,22 & 8,82 & 273,04 & 10,50 & 5715,26 & 12,2 \\
\hline $\begin{array}{l}\text { Pobres em } \\
\text { bairros } \\
\text { consolidados }\end{array}$ & 1625,8 & 23,9 & 2619,1 & 22,6 & 495,9 & 20,8 & 629,9 & 30,1 & 3207,6 & 27,6 & 579,4 & 47,3 & 2287,33 & 26,96 & 778,17 & 29,93 & 12 226,94 & 26,1 \\
\hline $\begin{array}{c}\text { Classe média } \\
\text { baixa }\end{array}$ & 1261,6 & 18,5 & 2180,7 & 18,8 & 632,8 & 26,5 & 617,9 & 29,6 & 3477,6 & 29,9 & 284,2 & 23,2 & 2 122,19 & 25,02 & 168,78 & 6,49 & 10758,72 & 22,9 \\
\hline Classe média & 1639,8 & 24,1 & 2995,8 & 25,8 & 319,6 & 13,4 & 142,8 & 6,8 & 820,1 & 7,1 & 91,4 & 7,5 & 2021,23 & 23,83 & 1206,25 & 46,39 & 9245,42 & 19,7 \\
\hline Classe alta & 1021,9 & 15,0 & 454,1 & 3,9 & 47,5 & 1,9 & 85,6 & 4,1 & 718,9 & 6,2 & 202,9 & 16,6 & 1 113,09 & 13,12 & 165,68 & 6,37 & 3810,58 & 8,1 \\
\hline Centro & 812,1 & 11,9 & 434,7 & 3,8 & 6,1 & 0,3 & 0,4 & 0,0 & 2018,0 & 17,3 & 14,1 & 1,2 & 190,60 & 2,25 & 8,27 & 0,32 & 3484,40 & 7,4 \\
\hline Total & 6812,7 & 100 & 11604,2 & 100 & 2385,5 & 100 & 2091,4 & 100 & 11635,0 & 100 & 1225,9 & 100 & 8482,65 & 100 & 2600,19 & 100 & 46896,57 & 100 \\
\hline \multicolumn{19}{|l|}{ Espaços } \\
\hline $\begin{array}{c}\text { Classes } \\
\text { baixas }\end{array}$ & 2077,3 & 30,5 & 4329,3 & 37,3 & 977,5 & 40,9 & 1222,6 & 58,5 & 4600,4 & 39,5 & 633,28 & 51,7 & 3035,55 & 35,79 & 1051,21 & 40,43 & 17942,21 & 38,3 \\
\hline Classes altas & 2661,7 & 39,1 & 3449,9 & 29,7 & 367,1 & 15,4 & 228,4 & 10,9 & 1538,9 & 13,2 & 294,25 & 24,0 & 3134,32 & 36,95 & 1371,93 & 52,76 & 23814,72 & 50,8 \\
\hline $\begin{array}{c}\text { Classes } \\
\text { médias baixas }\end{array}$ & 1261,6 & 18,5 & 2180,7 & 18,8 & 632,8 & 26,5 & 617,9 & 29,6 & 3477,6 & 29,9 & 284,24 & 23,2 & 2122,19 & 25,02 & 168,78 & 6,49 & 10758,72 & 22,9 \\
\hline
\end{tabular}

Fonte: Diários Oficiais do Município. 
Como podemos ver, o governo Olavo Setúbal apresenta um certo equilíbrio na distribuição dos investimentos, com gastos em áreas de classe média e de pobres em bairros consolidados, com cerca de $24 \%$, e classe média baixa e classe alta, entre 15 e $20 \%$. Comparativamente, a sua administração destacou-se pela elevada proporção de investimentos para classe alta.

A administração de Reynaldo de Barros caracterizou-se pelo alto investimento em espaços de classe média, áreas de pobres em bairros consolidados, ambos com mais de $20 \%$, e pelos investimentos em áreas de classe média baixa, com 19\%. Reynaldo apresentou ainda baixos investimentos em áreas da classe alta e no centro tradicional.

A maior proporção de investimentos per capita da administração de Salim Curiati ocorreu nas áreas de classe média baixa $(26,5 \%)$. Sua curta administração caracterizou-se também pelos investimentos em áreas de pobres recentes e consolidados (em torno de 20\%).

A administração Covas destacou-se por seu caráter redistributivo, com elevadas proporções dos investimentos destinados às periferias. Nesse governo, cerca de $30 \%$ dos investimentos foram para áreas de pobres consolidados e para espaços de classe média baixa e $28 \%$ para áreas de pobres em bairros recentes.

O centro tradicional recebeu os maiores investimentos relativos na administração Jânio Quadros: 17,3\%, R\$ 2 018,00 pc. O governo de Jânio também apresentou significativos investimentos pc em áreas de classe média baixa e em áreas de pobres em bairros consolidados (entre R\$ 3 000,00 e R\$ 3500,00 pc).

A exemplo do governo Covas, a administração Erundina destacou-se por um padrão distributivo de inversões, com os maiores investimentos relativos em áreas habitadas por pobres em bairros consolidados $(47,3 \%)$. Os investimentos em espaços de classe média baixa também foram bastante expressivos $(23,2 \%, \mathrm{R} \$ 284,00 \mathrm{pc})$.

Os maiores investimentos per capita em espaços de ricos encontram-se na administração Maluf (R\$ 1 113,00 pc). A administração Maluf apresenta percentagens equilibradas de investimentos em áreas de pobres consolidados $(26,96 \%)$, em espaços de classe média baixa $(25,0 \%)$, e em áreas de classe média $(23,8 \%)$.
Considerando que essa administração apresentou elevados volumes de repasses para a EMURB (cerca de R\$1,3 bilhão, 38\% do total dos repasses), e que sabemos que a maior parte desses recursos foi usada na região sudoeste, ocupada predominantemente por ricos e classe média (ver Mapa 1), a concentração de seus investimentos em áreas de ricos seria ainda maior se tivéssemos acesso às obras da EMURB.

Por fim, a administração Pitta pode ser caracterizada pelos maiores investimentos relativos em áreas habitadas pela classe média: 46,4\%, R\$ 1206,00 pc. Em segundo lugar, nos investimentos de Pitta, destacam-se os espaços de pobres em bairros consolidados, com cerca de $30 \%$ do total, o que corresponde a $\mathrm{R} \$ 778,00 \mathrm{pc}$.

A Tabela 2 também apresenta os investimentos nos espaços polares socialmente. Podemos ver que nas administrações Setúbal, Maluf e Pitta as áreas que receberam os maiores investimentos foram as das classes altas. Nas administrações Reynaldo, Jânio e Curiati, o espaço que individualmente mais recebeu investimentos foi o das classes baixas, mas a soma das classes altas com o espaço da classe média baixa ultrapassou o destinado àquele primeiro. No governo Reynaldo, os investimentos em classes altas superaram os da classe média baixa, enquanto no governo Jânio a classe média baixa recebeu uma proporção mais elevada. Essa foi a administração a investir mais nesse tipo de espaço, o que é coerente com os seus vínculos eleitorais. No governo Curiati, a diferença entre os investimentos para classes baixas e para outros espaços é mais significativa que nas administrações anteriores. As gestões Covas e Erundina, por fim, também investiram mais em espaços habitados pelas classes baixas, mas esse tipo de espaço recebeu mais do que o destinado aos demais espaços somados. Apenas nesses dois governos os investimentos nas classes baixas foram predominantes, superando $50 \%$ do total investido, o que nos permite sustentar o seu caráter distributivo.

As proporções de investimentos nos espaços, portanto, demonstram mais uma vez a importância do perfil político-ideológico do prefeito. Em termos estatísticos, não há diferenças significativas das proporções investida em áreas das classes altas e média-baixas por administrações de direita e não de direita. Entretanto, a análise quantitativa indica a existência de proporções mais altas de investimento em espaços das classes baixas em go- 
vernos não de direita do que em governos de direita $^{26}$. Isso confirma a impressão predominante da descrição dos investimentos por governo apresentada na seção anterior, além de corroborar a clivagem ideológica entre governos baseada na busca da equidade.

\section{CONCLUSÃO}

Podemos agora revisitar os elementos explicativos discutidos no início do artigo, à luz das informações da Secretaria de Vias Públicas.

Um primeiro conjunto importante de conclusões refere-se aos condicionantes dos volumes anuais de investimento. Inicialmente, descobrimos uma ausência de ligação entre o perfil geral de investimentos da SVP e o ciclo eleitoral. Por outro lado, foi encontrada uma importante relação entre o perfil político-ideológico do administrador e seu padrão de investimentos. Os maiores investimentos tendem a acontecer em administrações controladas por partidos de direita, que tendem a investir mais em grandes contratos de elevado valor unitário, aditá-los em valores mais altos, inclusive acima dos limites legais, assim como contratar empresas de capital médio mais elevado. Além disso, há uma sólida tendência dos governantes não de direita a investir mais, proporcionalmente, em espaços habitados por grupos sociais de piores condições sociais do que os governantes de direita. Em ambos os casos, estamos diante da relevância do campo da política.

Em segundo lugar, inúmeras questões relevantes relacionam-se com a descoberta de investimentos precoces nas periferias. A existência desses investimentos contraria a lógica do Estado capturado pelos interesses do capital, elemento destacado especialmente pela literatura marxista de corte estruturalista. De uma forma mais ampla, a precocidade desses investimentos problematiza a aplicação direta do modelo do conflito, segundo o qual as alterações do comportamento estatal seriam derivadas de pressões políticas dos movimentos sociais. Os investimentos indicam que áreas habitadas por pobres em bairros recentes foram mais beneficiadas no início do período

26 Usando testes de médias, as médias e os desvios padrões das proporções dos investimentos de governos de direita e não de direita para classes baixas são, respectivamente: 37,4 e 3,9\% e 55,1 e 4,8\%. A significância é de $0,2 \%$. estudado, quando a articulação política de base já estava ativa, embora fosse localizada no espaço e dispersa nas suas demandas. Isoladamente, esse elemento pouco esclarece. Como explicar que os investimentos tenham sido direcionados para um bairro, ao invés de outro? Assim como no caso do vínculo eleitoral, esse elemento pode (e deve) ser usado na explicação dos investimentos, mas de maneira não mecânica.

Propomos aqui um mecanismo mais complexo. Acreditamos que mobilizações incipientes tenham levado a ações estatais também incipientes, que potencializaram as mobilizações em ações coletivas mais amplas. Mais do que produto da ação de movimentos dispersos, mas crescentes, nas periferias, os investimentos estatais estão relacionados à interação entre mobilizações e ação do Estado.

Vale destacar que, apesar dos investimentos precoces nas periferias, as áreas de classe alta receberam, no conjunto do período, investimentos mais volumosos do que os espaços das classes baixas. Isso demonstra que a existência de investimentos expressivos nas periferias não significa necessariamente a reversão da segregação sócioespacial. Um elemento central na perpetuação desse padrão está ligado à cultura técnica do setor, e diz respeito à seletividade hierárquica das políticas descrita anteriormente.

A questão central a considerar é que se trata de um momento de mudança do cálculo político dos ocupantes de cargos públicos, com o crescimento da importância do vínculo eleitoral ${ }^{27}$, e o aumento da relevância de políticas redistributivas na construção das carreiras políticas. A mudança do ambiente incide fortemente sobre a forma como se constrói a agenda da classe política e das elites burocráticas, assim como sobre o seu conteúdo. Como os cálculos desses atores estão informados por um referencial fortemente conservador e hierárquico, está aberto o caminho para deslocamentos na ação do Estado, mas não para a reversão completa da produção estatal de segregação sócio-espacial.

Portanto, ao contrário do elo causal conside-

27 Embora, no Brasil, o vínculo eleitoral nunca tenha sido quebrado completamente, a sua importância no cálculo política das elites certamente se reduziu durante o regime militar. 
rado comumente, o início dos anos 1980 não assiste a um cenário no qual política (mobilizações) produz políticas (ações do Estado) (SKOCPOL, 1992). Em um ambiente político em transformação (e abertura), com a expectativa da expansão das eleições como forma de ascensão ao poder estatal, e sob crescente pressão vinda de baixo, as políticas geraram política, que gerou mais políticas.

Todos esses dados corroboram a complexidade do processo decisório das políticas da Secretaria. Como indicam as entrevistas realizadas com técnicos do setor, uma série de fatores, aparentemente contraditórios, porém articulados, contri- buem para a fixação das diretrizes de ação. Conjugados com a visão da cidade (e da sociedade) de cada administrador público, encontram-se definições técnicas de intervenção, prioridades traçadas por burocratas, pressões populares, lobbies de empreiteiras interessadas na utilização de certas soluções etc. O peso relativo de cada um desses elementos na efetivação das políticas é muito diferenciado em cada administração, de acordo com o seu perfil político-ideológico e as decisões no seu interior, o que mais uma vez indica a importância da política na produção do espaço.

Recebido para publicação em 10 de maio de 2001.

Eduardo Cesar Marques (ecmarq@uol.com.br) é Mestre em Planejamento Urbano pela Universidade Federal do Rio de Janeiro (UFRJ), Doutor em Ciências Sociais pela Universidade Estadual de Campinas (UNICAMP), Pesquisador da FAPESP no Centro Brasileiro de Análise e Planejamento (CEBRAP) e Professor convidado no Departamento de Ciência Política da Universidade de São Paulo (USP).

Renata Bichir é graduanda em Ciências Sociais na Universidade de São Paulo (USP) e pesquisadora da FAPESP no Centro Brasileiro de Análise e Planejamento (CEBRAP).

\section{REFERÊNCIAS BIBLIOGRÁFICAS}

AMENTA, E. \& SKOCPOL, T. 1986. States and Social Policies. Annual Review of Sociology, Cambridge, n. 12, p. 235-272.

AMES, B. 1995. Electoral Strategy under OpenList Proportional Representation. American Journal of Political Science, Madison, v. 39, n. 2, p. 406-433, May.

BLOCK, F. 1981. The Ruling Class Does Not Rule : Notes on the Marxist Theory of the State. In : FERGUSON, T. \& ROGERS, J. (org.). Political Economy. Nova York : M. E. Sharpe.

BONDUKI, N. \& ROLNIK, R. 1982. Periferia da Grande São Paulo : reprodução do espaço como expediente de reprodução da força de trabalho. In : MARICATO, E. (org.). A produção capitalista da casa e da cidade do Brasil industrial. São Paulo : Alfa-ômega.

BUENO, L. 2000. Projeto e favela : metodologia para projetos de urbanização. São Paulo. Tese (Doutorado em Estruturas Ambientais Urbanas). Universidade de São Paulo.

CASTELLS, M. 1983. A questão urbana. Rio de Janeiro : Paz e Terra.
D'ALESSANDRO, M. 1999. Avaliação da política de urbanização de favelas em São Paulo - 1989/92. São Paulo. Dissertação (Mestrado em Administração Pública). Fundação Getúlio Vargas.

FARIA, V. 1992. A conjuntura social brasileira : dilemas e perspectivas. Novos Estudos CEBRAP, São Paulo, n. 33, p. 103-114, jul.

FERREIRA, L. 1993. Positivistas e antipositivistas : notas sobre a origem da Academia Brasileira de Ciências. Ciência hoje, Rio de Janeiro, v. 16, n. 96, p. 112-121, jul.

FIZSON, J. 1990. A politica nacional de saneamento de 1968 a 1984 : o caso do PLANASA. Rio de Janeiro. Dissertação (Mestrado em Saúde Pública). Fundação Instituto Oswaldo Cruz/Escola Nacional de Saúde Pública.

GOHN, M. 1991. Movimentos sociais e luta pela moradia. São Paulo : Loyola.

GOMES, A. (org.). 1994. Engenheiros e economistas : novas elites burocráticas. Rio de Janeiro : FGV.

GUIMARÃES, R. \& TAVARES, R. 1994. Saúde 
e sociedade no Brasil dos anos 80. Rio de Janeiro : Relume-Dumará.

HARVEY, D. 1982. O trabalho, o capital e o conflito de classes em torno do ambiente construído nas sociedades capitalistas avançadas. Espaço e debates, São Paulo, ano II, n. 7, p. 6-35, set.

JACOBI, P. 1989. Movimentos sociais e políticas públicas. São Paulo : Cortez.

JOBERT, B. \& MULLER, P. 1987. L'État en action : politiques publiques et corporatismes. Paris : PUF.

KOWARICK, L. 1979. A espoliação urbana. São Paulo : Paz e Terra. 34.

2000. Escritos urbanos. São Paulo : Editora

KOWARICK, L. \& CAMPANÁRIO, M. 1988. São Paulo : metrópole do subdesenvolvimento industrializado. In : KOWARICK, L. (org). As lutas sociais e a cidade : São Paulo : passado e presente. São Paulo : Paz e Terra.

LEME, M. 1991. A formação do pensamento urbanístico em São Paulo, no início do século XX. Espaço e debates, São Paulo, ano XI, n. 34, p. 64-70.

(org.). 1999. Urbanismo no Brasil 1895/ 1965. São Paulo : Nobel.

LOJKINE, J. 1981. O Estado capitalista e a questão urbana. São Paulo : Martins Fontes.

MARICATO, E. 1996. Metrópole na periferia do capitalismo : ilegalidade, desigualdade $\mathrm{e}$ violência. São Paulo : Hucitec.

2000. Estado e redes sociais. Permeabilidade e coesão nas políticas urbanas no Rio de Janeiro. Rio de Janeiro : Revan/FAPESP.

MARQUES, E. 1997. Notas críticas sobre a literatura sobre Estado, políticas estatais e atores políticos. Boletim bibliográfico de Ciências Sociais, Rio de Janeiro, n. 43, p. 67$102,1^{\circ}$ semestre.

1998. Os modelos espaciais como instrumento para o estudo de fenômenos urbanos. In : NAJAR, A. \& MARQUES, E. (org.).Saúde e espaço : estudos metodológicos e técnicas de análise. Rio de Janeiro : Fiocruz.

2000. Estado e redes sociais : permeabilida- de e coesão nas políticas urbanas no Rio de Janeiro. Rio de Janeiro : Revan/FAPESP.

MARQUES, E. \& BICHIR, R. 2001. Padrões de investimento estatal em infra-estrutura viária em São Paulo, 1978-98. São Paulo em perspectiva, São Paulo, v. 14, n. 4, no prelo.

OSTROWSKY, M. 1989. Urbanização e controle de enchentes. O caso de São Paulo, seus conflitos e inter-relações. São Paulo. Dissertação (Mestrado em Engenharia). Escola Politécnica, Universidade de São Paulo.

SÃo PAUlO. PREFEITURA MUNICIPAL. 1992. O poder em São Paulo : história da Administração Pública da Cidade. São Paulo : Cortez/PMSP.

RIBEIRO, L. 1997. Dos cortiços aos condomínios fechados : as formas de produção da moradia no Rio de Janeiro. Rio de Janeiro : Civilização Brasileira.

SADER, E. 1988. Quando novos personagens entram em cena. São Paulo : Paz e Terra.

SANTOS, C. 1982. Processo de crescimento e ocupação da periferia. Rio de Janeiro : IBAM/ CPU.

SANTOS, C. \& BRONSTEIN, O. 1978. Metaurbanização - o caso do Rio de Janeiro. Revista de Administração Municipal, Rio de Janeiro, v. 25, n. 149, p. 6-34, out.-dez.

SIMÕES JR., J. 1991. O setor de obras públicas e as origens do urbanismo moderno na cidade de São Paulo. Espaço e debates, São Paulo, ano XI, n. 34, p. 71-74.

SKOCPOL, T. 1992 Protecting Soldiers and Mothers : The Political Origins of Social Policy in the United States. Cambridge : Harvard University Press.

SOARES, G. 2000 Em busca da racionalidade perdida : alguns determinantes do voto no Distrito Federal. Revista brasileira de Ciências Sociais, São Paulo, n. 43, p. 5-24, jun.

TELLES, P. 1984. História da Engenharia no Brasil. Rio de Janeiro : Clube de Engenharia.

TORRES, H. \& MARQUES, E. C. 2001. Reflexões sobre a hiperperiferia : novas e velhas faces da pobreza no entorno metropolitano. Revista brasileira de estudos urbanos e regionais, Campinas, n. 4, no prelo. 
VETTER, D. 1975. The Impact on the Metropolitan System of the Interpersonal and Spatial Distribution of Real and Monetary Income : The Case of Grande Rio. Los Angeles. Tese (Doutorado em Planejamento Urbano). University of California.

WATSON, G. 1992. Water and Sanitation in São Paulo, Brazil: Successful Strategies for Service
Provision in Low-Income Communities. Cambridge. Dissertação (Mestrado em Planejamento Urbano). Massachussets Institute of Technology.

ZANCHETI, S. 1991. Formação e consolidação da Repartição de Obras Públicas de Pernambuco, 1836-1844. Espaço e debates, São Paulo, ano XI, n. 34, p. 75-83.

\section{OUTRAS FONTES}

DIÁRIO OFICIAL DO ESTADO DE SÃO

PAULO. 1978-1999. São Paulo: Imprensa Oficial do Estado de São Paulo.
Entrevistas com técnicos da SVP. Jul.2000jan.2001.

\section{ANEXO METODOLÓGICO: PRODUÇÃO DA BASE ESPACIAL}

Para proceder à distribuição dos investimentos, usamos uma base espacial que agrega espaços habitados por grupos populacionais similares, sob o ponto de vista sócio-econômico, seguindo as recomendações de Marques (1998). Esse procedimento tem por objetivo escapar dos problemas metodológicos que adviriam da utilização de um modelo pré-concebido de distribuição dos grupos sociais no espaço, como um modelo radialconcêntrico ou uma estruturação em setores circulares, induzindo o resultado pela forma de agrupar as informações.

Para a construção dessa base espacial, partimos de informações sócio-econômicas presentes na pesquisa de origem-destino (OD), realizada pela Companhia do Metrô, em 1997. Essa pesquisa tem as informações coletadas agrupadas pelas chamadas “Zonas OD”, que, no interior do município de São Paulo, totalizam 393. Considerando que os investimentos estudados não permitem uma localização de tão grande detalhe, essas zonas foram reagrupadas nos 96 distritos censitários utilizados pelo IBGE em 1991, utilizando para tanto um programa de informações geográficas (Maptitude).

Foram utilizadas as seguintes variáveis, presentes na pesquisa OD ou obtidas por manipulações algébricas a partir das variáveis da pesquisa: proporção da população do distrito habitante em favelas; idade média da população; informações sobre escolaridade - proporção da população sem escolaridade, com primeiro grau incompleto ou completo; com segundo grau completo ou curso superior completo; Informações sobre ocupação -; proporção da população do distrito com ocupação constante; com ocupação eventual; aposentados e pensionistas; não ocupados; informações sobre estabilidade do vínculo - assalariados sem carteira; assalariados com carteira; funcionários públicos; autônomos; empregadores; profissionais liberais; informações da mão de obra ocupada por setor - agrícola, construção civil, indústria, comércio, serviços em geral, serviços creditícios e financeiros, e administração pública; renda média da população do distrito, proporção da população que habita domicílios próprios; proporção da população que ocupa domicílios alugados, proporção dos habitantes que chegou ao bairro a menos de 10 anos e que chegou ao município há menos de 10 anos.

As informações das zonas foram então submetidas a análise fatorial por componentes principais. Os sete primeiros fatores apresentaram autovalores superiores a 1 , e os três primeiros superiores a 2,5 , verificando-se a partir daí uma queda nas diferenças entre os autovalores. Os coeficientes de correlação entre os fatores rotados e as variáveis originais indicam que os três primeiros fatores representam as características descritas no corpo do artigo.

Os três fatores foram submetidos a análise de cluster, que agregou as unidades em seis grupos e uma unidade isolada. Essa unidade - Marsilac - 
foi retirada da análise por ser atípica e não importante para a análise.

Os seis grupos-unidade foram caracterizados pelos seus fatores médios, apresentando os conteúdos já descritos no corpo do artigo. 